\title{
Thematic Analysis of the Content of the Friday Sermon in Negeri Sembilan
}

\author{
Mizzuan Jafilus, Mohd Faisal Asha'ari, Rosmawati Rasit
}

To Link this Article: http://dx.doi.org/10.6007/IJARBSS/v11-i6/10087

DOI:10.6007/IJARBSS/v11-i6/10087

Received: 12 March 2021, Revised: 14 April 2021, Accepted: 27 April 2021

Published Online: 06 May 2021

In-Text Citation: (Jafilus et al., 2021)

To Cite this Article: Jafilus, M., Asha'ari, M. F., \& Rasit, R. (2021). Thematic Analysis of the Content of the Friday Sermon in Negeri Sembilan. International Journal of Academic Research in Business and Social Sciences, 11(6), 84-98.

\section{Copyright: (c) 2021 The Author(s)}

Published by Human Resource Management Academic Research Society (www.hrmars.com)

This article is published under the Creative Commons Attribution (CC BY 4.0) license. Anyone may reproduce, distribute, translate and create derivative works of this article (for both commercial and non-commercial purposes), subject to full attribution to the original publication and authors. The full terms of this license may be seen at: http://creativecommons.org/licences/by/4.0/legalcode

\section{Vol. 11, No. 6, 2021, Pg. 84- 98}

Full Terms \& Conditions of access and use can be found at http://hrmars.com/index.php/pages/detail/publication-ethics 


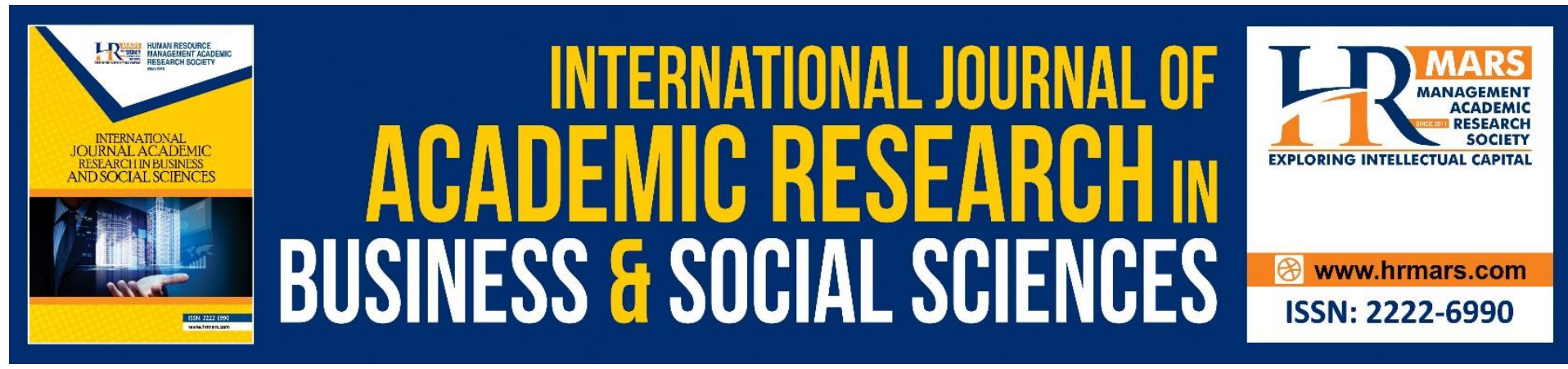

\title{
Thematic Analysis of the Content of the Friday Sermon in Negeri Sembilan
}

\author{
Mizzuan Jafilus, Mohd Faisal Asha'ari, Rosmawati Rasit \\ Research Centre for Da'wah and Leadership Studies, Faculty of Islamic Studies, \\ National University of Malaysia
}

\begin{abstract}
The mosque is a superior institution in building the unity of the ummah in addition to the development of the spiritual element of each individual. The Malaysian Mosque Rating Standard (SPMM) developed by the Department of Islamic Development Malaysia (JAKIM), is an instrument in measuring the level of achievement of mosques in service delivery. The four main components arranged as a measure are management, entertainment, infrastructure facilities, and the environment. One of the criteria assessed was the implementation of Friday sermon delivery through document review methods, structured observations, and interviews with mosque worshipers by appointed panels. The assessment proves the importance of the sermon in contributing to the development of the ummah in a place. The sermon is a weekly da'wah platform delivered by the preacher on the pulpit in the form of religious advice or messages. It is not only a basis for motivation for the improvement of spiritual practices as organized by Imam al-Ghazali in the process of mental training (riyadhah al-nafs), but it is also a reminder and guide to Muslims during the week. However, some researchers still voice weaknesses and gaps in the content of the sermon text so that the content is not seen to have a profound impact and impact on the congregation. Therefore, this study aims to examine the content theme of the Friday sermon that is most frequently discussed in the Friday sermon. This study uses a qualitative method with content analysis method on the text of the Friday sermon for the year 2019 which is uploaded in the official website of the Negeri Sembilan Islamic Religious Affairs Department (JHEAINS). The results of this study will be able to analyze the frequency of themes discussed and presented in the sermon in Negeri Sembilan.
\end{abstract}

Keywords: Sermon, Thematic Analysis, Negeri Sembilan Religious Affairs Department

\section{Introduction}

Friday prayers are like a ceremony for Muslims to gather weekly to perform prayers and meet as well as listen to messages from the preacher for the week. The message from the preacher is very important to remind the community and provide guidance because all Muslims gather on that day. However, one of the aspects that guarantee its effectiveness is its content (Erwin, 2014) because it can explain many things in detail that are strengthened by strong facts and propositions. Friday sermon is a mandatory pillar in Friday prayers and is a medium da'wah specifically for Muslim men. Usually, the text of the Friday sermon revolves around problems 
or issues that arise among the Muslim community delivered by the preacher from the pulpit. (Hamid, 2019).

From the field of Arabic knowledge, the term khutbah is a derivative name from the verb khatabah which means to have spoken. While the word khatabah means speech and khitabah means rhetoric, oratory, speech, lecture, and discourse. In terms of terminology, the word khutbah is the word mufrad khataba which comes from the word masdarnya al-khitab which means speech on the pulpit or the words spoken. While the word khutbah is isim kalam means the word or speech of the preacher. In terms of verbs, khatabah means speech delivered on the pulpit. In Arabic literature, sermons are the art of speech spoken to the public for satisfaction as well as to attract attention through the way of hearing and seeing (Ghazali, tth).

Friday Sermon means a speech spoken by a preacher. Sermons are also defined as speeches or lectures that contain religious teachings or advice (Hassan, 2018). Friday sermons play an important role in the formation of the Muslim community to be the best individual in line with the guidelines and Syariah that have been set by Islam. A sermon is one of the forms of da'wah that is delivered orally (Bani 'Amir, 1999) and is one of the methods of da'wah, namely al-maw'izah al-hasanah. From the time of ignorance, the sermon has been one of the mediums of communication in conveying advice and messages to the community covering various aspects of daily life involving morals, worship, faith, muamalah, and sharia. As the hadith narrated by al-Baihaqi that Rasulullah S.A.W has said which means:

"Indeed, I state that the sermon is a reminder."

In Negeri Sembilan in particular, the Negeri Sembilan Islamic Religious Affairs Department (JHEAINS) has prepared sermon texts written by a panel of appointed writers consisting of senior State Mosque officials, senior JHEAINS officials, Mosque Executives in Negeri Sembilan, and from various backgrounds from agencies selected. In the preparation of the sermon text, there is a series of workshops conducted to ensure its preparation based on the theme, content, and facts concerning the Guidelines for the Friday Sermon Negeri Sembilan. To ensure the quality of the sermon text to be published, JHEAINS ensures that it must go through procedures such as the selection of sermon titles throughout the year (taqwim), preparation of text synopsis, writing text by panels, text review by panel reviewers, typing and rendering text and uploading to the site JHEAINS official website. In response to the paperless approach, JHEAINS no longer prints sermon texts on behalf of mosques and suraus on Fridays, it is sufficient for committees or preachers to download digital texts for use on Fridays.

\section{Research Problems}

Often looking at the atmosphere when the Friday sermon is delivered, we will never miss seeing the phenomenon of lethargy, delusion, laziness playing gadgets, and some even chatting with friends. Have we ever wondered what is the cause of all this?. No less than that, there are a handful of individuals who deliberately miss and casually attend the mosque on Fridays so as not to have to wait long for the sermon to be delivered. Feeding a thirsty throat under a hawker umbrella in the mosque parking lot while chatting and lighting a couple of cigarettes is a common sight. This is one of the challenges in the delivery of a sermon. The 
challenge also increases when it comes to ensuring that the sermon delivered has a place in the hearts of the congregation and is then appreciated and practiced in daily life. As stated by Hamdan Y, 2015 in his study, the Friday sermon has not reached the level of an effective communication medium to Muslims due to the factors of the preacher, the content, and the body that publishes it.

Through previous studies, there are several factors identified as contributing to this problem. In the study of Moiden, Hamid (2013) who analyzed language errors in the text of the sermon, they found that errors in language will inhibit the message to be conveyed to the congregation. It can also have the effect of lowering the reputation of the agency that published the text of the sermon. According to Corder (1973) also, language errors occur due to the speaker who changes, transitions or disappears utterances that are sounds, morphemes, words, or phrases that cause the formation of sentences that have errors in them. The function of language in general is a tool for expressing feelings or self-expression. Through the use of language, human beings will be able to openly convey what they think and feel in their hearts (As'ad, 2017)

The content of the sermon can be an effective medium of mass communication (Bakar, Tajudin \& Safian, 2007) At the federal level, the text of the sermon was prepared by the Department of Islamic Development Malaysia (JAKIM) which aims to control the content of the sermon so as not to touch on political issues and control racially sensitive issues. In fact, in each state, the State Islamic Religious Department (JAIN) plays a role in publishing the text of their sermons so that it can follow current developments in each state. The preparation of the sermon text based on the guidelines is done carefully so that the content is in line with the current topic. Similarly, in public speaking, delivery requires the structuring of speech so that the listeners can pay attention, focus, understand and easily remember the essence of the speech they hear.

Various studies related to the text of the sermon were conducted to restore the objective of the sermon to invite the negligent to return to God, calm the arrogant soul, stimulate the spirit of sacrifice and jihad, strengthen the piety of those who listen, revive the dead, encourage the good, tell or teach the ignorant and be able to improve the standard of living of Muslims towards a more excellent and distinguished (Hassan, 2018).

Therefore, this study was conducted in Negeri Sembilan by analyzing the sermon texts published by JHEAINS. This study aims to determine the theme that is the basis for the preparation and writing of sermon texts in Negeri Sembilan throughout 2019. The results of this study are expected to list existing themes and see the relationship between themes and current developments in dakwah and efforts to improve the spirituality of the Muslim community in the state.

\section{Result and Discussions}

Referring to the content of the text of the Friday Sermon delivered on weekly basis, it has to do with the appreciation of religion. Appreciation comes from the word 'life' which is life while in terms of verbs, it means to feel, experience (with the mind), or permeate into one's soul (Osman, 2002). The word religion is derived from the Sanskrit word from a combination of 'a' which means no and 'gama' which means to stir and then the word 'religion' is interpreted as 
not to stir or rule. Following that purpose, the religious person is associated as a human being who has external and internal peace. A person who appreciates religion will always make the religious beliefs 'live' in him outwardly and inwardly. Then, it will translate into good deeds and behaviors. Thus, a person's actions and way of life whether good or bad will be visible as it is influenced by his appreciation of religion.

In the Muslim context, the concept of appreciating religion is to appreciate religion in every aspect of life as a whole based on 3 aspects, namely faith, morality, and worship which are closely related to the inner or spiritual. The appreciation of religion for these 3 aspects brings the meaning of faith as a way of life to be lived, noble morals as an ethic of life, worship as a practice of life including avoiding acts prohibited by Allah S.W.T such as shirk, disbelief, and so on (Zulkiple, 2006).

Faith is the main pillar of faith and piety to God. Faith is like the support of a tree. If the trunk is strong, then the tree will also be strong. In Arabic, aqidah comes from the root word 'aqada which means"tie". The word al-'aqd also carries the meaning of law, assurance, and agreement such as oath, marriage contract, and sale, and purchase agreement. The word 'aqidah or the plural word' aqa'id, means anything related to belief and creed does not include aspects of practice. Another meaning is the law that is no doubt for an individual. The creed which comes from the verb 'aqoda, ya'qidu' also means a strong and firm bond or knot like a rope (Khalid, 2017)

The word akidah is not found in the Quran, but the basic word 'aqoda عقد) has been mentioned seven times in five different surah, namely in surah al Maidah verses 1 and 89, surah al Baqarah verse 235, surah al nisa' verse 33, surah Thaaha verse 27 and surah al Falaq verse 4. The basis of the beliefs of Muslims in Malaysia is based on the Ahli al-Sunnah wa alJama` ah. Muzakarah Jawatankuasa Fatwa Kebangsaan Malaysia has also decided that only Mazhab Ahli Sunnah wa al-Jam'ah is adopted in this country, The practice of other mazhabs is not allowed to be practiced or disseminated among the community (Hamat, 2008).

The rulers (umara ') and scholars have a very important responsibility in ensuring that the Muslim community is always obedient and obedient in preserving the faith today. Their responsibility is not only to forbid or prevent the Muslim community from committing immorality and enjoining in doing good deeds (al-amr bi al-ma'ruf wa al-nahy 'an al munkar), but also the weight of their responsibility to ensure the religion (hifz al-din ) protected from misguided and wrong beliefs. Therefore, Sa id Hawwa has stated that the main task of the scholars is that they are responsible for warning (inzar) and intimidating (takhwif) people with the threat of punishment regarding the care of religion and questions and answers related to faith. Therefore, one of the mediums used to convey this message is through the Friday sermon (Jasni, 2016)

The second element of religious appreciation that is also touched on in the Friday sermon is also the topic of worship. Worship is defined as submission (Thaat), doing devotion (Tanassuk), humility (Khudlu '), humiliation (Tadzallul), and istrkhanah. Worship from the root word 'Abd which means servant and slave. In particular, worship carries the meaning of servitude. Worship is also an effort to always follow the laws and rules and regulations that God has set in living a life by His commandments, beginning with the advent of puberty until 
death. The context of worship can also be understood as loyalty, obedience, respect, and appreciation to Allah SWT and performed without any time constraints or obstacles and certain special forms. Any practice that is done if it is not contrary to the Syariah of Allah SWT and the guidelines set by Islam is a noble act of worship if it is based on a sense of sincerity to do it (Khalid, 2017).

There are two types of worship, namely special worship and 'aam worship. Special worship is worship related to the pillars of Islam such as reciting the two words of syahadah, prayer, zakat, fasting, and hajj). Whereas, ibadah 'Aam is any deed or sincere pious deed done to achieve the pleasure and enlightenment of Allah. Regarding the importance of worship, it is enough if we know that the purpose of the creation of the universe and the sending of the prophets is to worship and enslave oneself to Allah as Allah has said in the Qur'an:

Meaning: "I did not create the jinn and humans except to worship Me."

(al Quran, Surah Adz-Dzariyat: 5)

In increasing piety and steadfastness in worship, human beings must always be reminded and instructed in knowledge gatherings such as the Friday sermon. Through this medium, it can indirectly revive the dead souls, remind the forgetful and negligent human beings and even strengthen the piety of the hearers to be more zealous in performing worship and draw closer to Allah S.W.T.

Next, the third element is morality. Islam is a religion that is very concerned about the well-being of the people. The application of morality in every Muslim individual is important to shape the life of a Muslim community that is obedient and obedient to the guidelines that have been set in Islam. The destruction of a civilization can also occur when there is a moral defect in the life of the society. Imam Ghazali has said that indeed morality refers to the nature that is stored in the heart and published to the limbs in terms of words and deeds. (Husain, 2006)

The word "morality" is derived from a word in Arabic, which means manners, temperament, behavior (habits), and customs. Morality is defined as character, behavior, habits, and character. (Dictionary of the Council, 1992). Morality in terms of the term is defined as an analogy of a fixed self -behavior and out of it some actions easily and simply without the need for thought. If the behavior that is highlighted is a good deed in terms of shari'ah and the logic of reason easily, then it is called the behavior as good morals. Similarly, on the other hand, if the behavior that is highlighted is a heinous act, then the behavior is called bad morals (Asming, 2007)

Therefore, this topic of morality is appropriate and important to be conveyed through the Friday sermon. This is because moral education among the Muslim community is very necessary to curb moral behavior that is contrary to the teachings of Islam and subsequently form a Muslim community that has the best personality. Priority to noble morals in all deeds can have a positive effect on human daily life. Morality is a legacy left by the Prophet to his people as a hadith from Abu Hurairah RA that the Prophet SAW said,

Meaning: "Indeed, I was not sent except to perfect the moral good." 
Based on the 3 conceptual elements that have been described above, this study focuses on the themes discussed in the text of the Friday sermon in Negeri Sembilan delivered by the preacher every week. The number of Friday sermons throughout 2019 is 60 . From the total weekly topics, 3 elements of religious appreciation have been identified, namely the elements of faith, worship, and morality. There are 28 sermon texts themed on worship, followed by 23 sermon texts themed on morality and 9 sermon texts themed on faith. The researcher has categorized through table 1 below:

A Brief Thematic Analysis of the Text of the Friday Sermon Published by JHEAINS Year 2019

\begin{tabular}{|c|c|c|c|c|c|c|}
\hline Months & & Title & & Review & & me \\
\hline January & $\begin{array}{l}\text { ? } \\
\text { ? } \\
\text { ? } \\
\text { ? }\end{array}$ & $\begin{array}{l}\text { Love of God's } \\
\text { belongings } \\
\text { The importance of } \\
\text { educating children in } \\
\text { shaping The Ummah's } \\
\text { personality. } \\
\text { Great Muslims away } \\
\text { from illegal things. } \\
\text { Sincerely lock up the } \\
\text { deeds. }\end{array}$ & $\begin{array}{l}\text { 回 } \\
\text { ? } \\
\text { 回 }\end{array}$ & $\begin{array}{l}\text { Love for God is } \\
\text { the most noble } \\
\text { love and remains } \\
\text { forever. } \\
\text { The importance } \\
\text { of building human } \\
\text { capital to children } \\
\text { and people today. } \\
\text { Great Muslims } \\
\text { have great goals } \\
\text { and enthusiasm. } \\
\text { Doing a worship } \\
\text { or act must be } \\
\text { sincere and intent } \\
\text { on Allah. }\end{array}$ & $\begin{array}{l}\text { ? } \\
\text { ? } \\
\text { ? } \\
\text { ? }\end{array}$ & $\begin{array}{l}\text { Faith } \\
\text { Moral } \\
\text { Faith } \\
\text { Worship }\end{array}$ \\
\hline February & $\begin{array}{l}\text { ? } \\
\text { 回 } \\
\text { 回 } \\
\text { ? }\end{array}$ & $\begin{array}{l}\text { To enroke converts } \\
\text { of mutual } \\
\text { responsibility. } \\
\text { Love is empowered, } \\
\text { the family is happy. } \\
\text { The prohibition of } \\
\text { insulting fellow human } \\
\text { beings. } \\
\text { Effect of beliamity in } \\
\text { the Day of Judgment. }\end{array}$ & 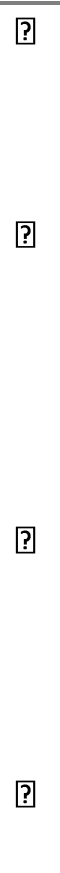 & $\begin{array}{l}\text { Definition of } \\
\text { converts \& } \\
\text { challenges they } \\
\text { face } \\
\text { The } \\
\text { characteristics of a } \\
\text { happy family and } \\
\text { the cause of the } \\
\text { collapse of a family } \\
\text { institution. } \\
\text { Current issues } \\
\text { concerning the } \\
\text { contempt of fellow } \\
\text { human beings } \\
\text { nowadays. } \\
\text { The effects when } \\
\text { a believer in the }\end{array}$ & $\begin{array}{l}\text { ? } \\
\text { ? } \\
\text { 目 } \\
\text { 圆 }\end{array}$ & $\begin{array}{l}\text { Faith } \\
\text { Moral } \\
\text { Moral } \\
\text { Faith }\end{array}$ \\
\hline
\end{tabular}


Day of Judgment is

obedient to Allah,

\begin{tabular}{|c|c|c|c|c|c|c|}
\hline Mac & $\begin{array}{l}\text { ? } \\
\text { 回 } \\
\text { ? } \\
\text { ? } \\
\text { ? }\end{array}$ & $\begin{array}{l}\text { Worship every } \\
\text { second } \\
\text { Our community is } \\
\text { our responsibility } \\
\text { Al Quran pedoman } \\
\text { ummah throughout } \\
\text { the ages. } \\
\text { Establish aqidah by } \\
\text { knowing Allah. } \\
\text { Default in the world, } \\
\text { losers in the hereafter. }\end{array}$ & $\begin{array}{c} \\
0 \\
0\end{array}$ & $\begin{array}{l}\text { The definition of } \\
\text { worship and its } \\
\text { demands to } \\
\text { mankind. } \\
\text { The } \\
\text { disadvantages of } \\
\text { the drug and the } \\
\text { effects of abuse to } \\
\text { the addicts and } \\
\text { efforts of NADA. } \\
\text { those and beliefs } \\
\text { that reject the } \\
\text { hadith of the tone } \\
\text { that interprets the } \\
\text { verse of the quran } \\
\text { according to desire. } \\
\text { Congregations } \\
\text { are urged to } \\
\text { strengthen worship } \\
\text { because the } \\
\text { strengthening of } \\
\text { aqidah can be } \\
\text { generated through } \\
\text { perfect worship. } \\
\text { Guide to prevent } \\
\text { ghoflah diseases. }\end{array}$ & $\begin{array}{l}\text { ? } \\
\text { ? } \\
\text { 目 } \\
\text { 圆 } \\
\text { 圆 }\end{array}$ & $\begin{array}{l}\text { Worship } \\
\text { Moral } \\
\text { Faith } \\
\text { Worship } \\
\text { Worship }\end{array}$ \\
\hline April & $\begin{array}{l}\text { ? } \\
\text { 田 } \\
\text { ? }\end{array}$ & $\begin{array}{l}\text { Aqidah is } \\
\text { prosperous: a happy } \\
\text { condition in the } \\
\text { hereafter. } \\
\text { Sya'ban: Gateway } \\
\text { Towards Ramadan } \\
\text { Bankruptcy in the } \\
\text { hereafter. } \\
\text { Road safety, our } \\
\text { responsibility is all. }\end{array}$ & $\begin{array}{l}\text { ? } \\
\text { 回 } \\
\text { ? }\end{array}$ & $\begin{array}{l}\text { The duty of } \\
\text { preserving aqidah. } \\
\text { Ramadan } \\
\text { specialty. } \\
\text { Discussed about } \\
\text { the characteristics } \\
\text { of bankruptcy in } \\
\text { the hereafter. } \\
\text { appreciate lives } \\
\text { The importance } \\
\text { of self-defense } \\
\text { knowledge. }\end{array}$ & 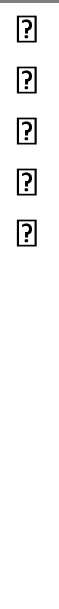 & $\begin{array}{l}\text { Aqidah } \\
\text { Worship } \\
\text { Worship } \\
\text { Worship } \\
\text { Worship }\end{array}$ \\
\hline
\end{tabular}




\begin{tabular}{|c|c|c|c|c|c|c|}
\hline May & $\begin{array}{l}\text { ? } \\
\text { ? } \\
\text { 回 } \\
\text { ? } \\
\text { ? }\end{array}$ & $\begin{array}{l}\text { Santuni Ramadhan } \\
\text { is best. } \\
\text { Ramadan is a month } \\
\text { of joy. } \\
\text { Al Quran guides } \\
\text { human life. } \\
\text { Double the practice } \\
\text { in late Ramdhan. } \\
\text { There is still a dear } \\
\text { one }\end{array}$ & $\begin{array}{l}\text { ? } \\
\text { 田 } \\
\text { 回 } \\
\text { ? } \\
\text { ? } 9\end{array}$ & $\begin{array}{l}5 \text { Guide in } \\
\text { spiritual and } \\
\text { physical } \\
\text { preparations facing } \\
\text { the month of } \\
\text { Ramadhan. } \\
\text { The advantages } \\
\text { of fasting people. } \\
\text { Calls to } \\
\text { commemorate the } \\
\text { events of the } \\
\text { decline of the } \\
\text { Quran. } \\
\text { Advantages of } \\
\text { Lailatul Qadr } \\
\text { Discussed about } \\
\text { the love of the } \\
\text { child towards } \\
\text { parents. }\end{array}$ & $\begin{array}{l}\text { ? } \\
\text { ? } \\
\text { ? } \\
\text { ? } \\
\text { ? }\end{array}$ & $\begin{array}{l}\text { Worship } \\
\text { Worship } \\
\text { Worship } \\
\text { Worship } \\
\text { Moral }\end{array}$ \\
\hline June & $\begin{array}{l}\text { ? } \\
\text { 圆 } \\
\text { 田 } \\
\text { ? } \\
\text { ? }\end{array}$ & $\begin{array}{l}\text { Syawal in the } \\
\text { election, sharia is } \\
\text { taken care of. } \\
\text { Istiqamah retained } \\
\text { the victory of syawal. } \\
\text { Expect rewards, } \\
\text { forged sins. } \\
\text { Walimah, between } \\
\text { will or sunnah. } \\
\text { Contribution of } \\
\text { Muslim scientists to }\end{array}$ & $\begin{array}{l}\text { ? } \\
\text { ? } \\
\text { ? } \\
\text { ? }\end{array}$ & $\begin{array}{l}\text { The sharia must } \\
\text { be taken care of } \\
\text { during hari raya } \\
\text { which is the } \\
\text { manner of mixing, } \\
\text { keeping the awrah, } \\
\text { pilgrimage and } \\
\text { charity. } \\
\text { methods and } \\
\text { guidelines in } \\
\text { celebrating hari } \\
\text { raya to Muslims. } \\
\text { guide in } \\
\text { organizing open } \\
\text { houses to coincide } \\
\text { with islamic sharia. } \\
7 \text { things to pay } \\
\text { attention to in } \\
\text { implementing } \\
\text { walimah } \\
\text { The factors led } \\
\text { to the glory of } \\
\text { science in Islamic } \\
\text { civilization. }\end{array}$ & $\begin{array}{l}\text { ? } \\
\text { ? } \\
\text { ? } \\
\text { ? } \\
\text { ? }\end{array}$ & $\begin{array}{l}\text { Moral } \\
\text { Worship } \\
\text { Moral } \\
\text { Moral } \\
\text { Worship }\end{array}$ \\
\hline
\end{tabular}




\begin{tabular}{|c|c|c|c|c|c|c|}
\hline July & 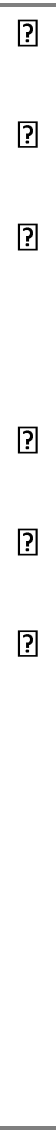 & $\begin{array}{l}\text { Halal food, military } \\
\text { soul. } \\
\text { Magic threatens } \\
\text { faith } \\
\text { The eclipse } \\
\text { phenomenon of } \\
\text { evidence of Divine } \\
\text { supreath. } \\
\text { Incest crime is } \\
\text { damned. } \\
\text { Fire safety of mutual } \\
\text { responsibility. } \\
\text { Strengthen faith, } \\
\text { subdue love. }\end{array}$ & ? & $\begin{array}{l}\text { Guide to } \\
\text { choosing and } \\
\text { purchasing halal } \\
\text { food. } \\
\text { The } \\
\text { disadvantages of } \\
\text { magic and its } \\
\text { effects on the faith. } \\
\text { Calls for the } \\
\text { grasp of Allah's } \\
\text { power. } \\
\text { Measures in } \\
\text { stemming the act } \\
\text { of incest. } \\
\text { Mutual interests } \\
\text { and responsibilities } \\
\text { to safeguard } \\
\text { security. } \\
\text { Calls for love, } \\
\text { keeping fraternity } \\
\text { and supporting } \\
\text { each other. }\end{array}$ & $\begin{array}{l}\text { ? } \\
\text { ? } \\
\text { ? } \\
\text { ? } \\
\text { ? } \\
\text { ? }\end{array}$ & $\begin{array}{l}\text { Moral } \\
\text { Faith } \\
\text { Faith } \\
\text { Moral } \\
\text { Moral } \\
\text { Moral }\end{array}$ \\
\hline August & $\begin{array}{l}\text { ? } \\
\text { ? }\end{array}$ & $\begin{array}{l}\text { Practice in the } \\
\text { month of Zulhijjah. } \\
\text { Loyalty to Teenagers } \\
\text { and Country. } \\
\text { Islam guarantees } \\
\text { social justice } \\
\text { National Security, } \\
\text { mutual prosperity. } \\
\text { Qurban grateful sign } \\
\text { Family institutions } \\
\text { fortress collapse } \\
\text { morality. } \\
\text { The afterlifer of my } \\
\text { goal } \\
\text { Call to defend Al- } \\
\text { Aqsa mosque } \\
\text { Grateful for } \\
\text { independence }\end{array}$ & ? & $\begin{array}{l}\text { The advantages } \\
\text { of making Zulhijjah } \\
\text { moon practice. } \\
\text { Calls to observe } \\
\text { the King and the } \\
\text { leader. } \\
\text { Issues on the } \\
\text { importance of } \\
\text { social justice } \\
\text { principles plunged } \\
\text { in Islam. } \\
\text { Make-up for } \\
\text { Congregation and } \\
\text { all Malaysians to } \\
\text { practice } \\
\text { harmonious and } \\
\text { tolerant ways of } \\
\text { life. } \\
\text { Praise be to God } \\
\text { as a sign of } \\
\text { gratitude and joy. } \\
\text { The role of } \\
\text { family institutions } \\
\text { and the whole } \\
\text { community in }\end{array}$ & $\begin{array}{l}\text { ? } \\
\text { ? } \\
\text { ? } \\
\text { ? } \\
\text { ? } \\
\text { ? } \\
\text { ? } \\
\text { ? } \\
\text { ? }\end{array}$ & $\begin{array}{l}\text { Worship } \\
\text { Moral } \\
\text { Worship } \\
\text { Worship } \\
\text { Worship } \\
\text { Worship } \\
\text { Worship } \\
\text { Worship } \\
\text { Worship }\end{array}$ \\
\hline
\end{tabular}




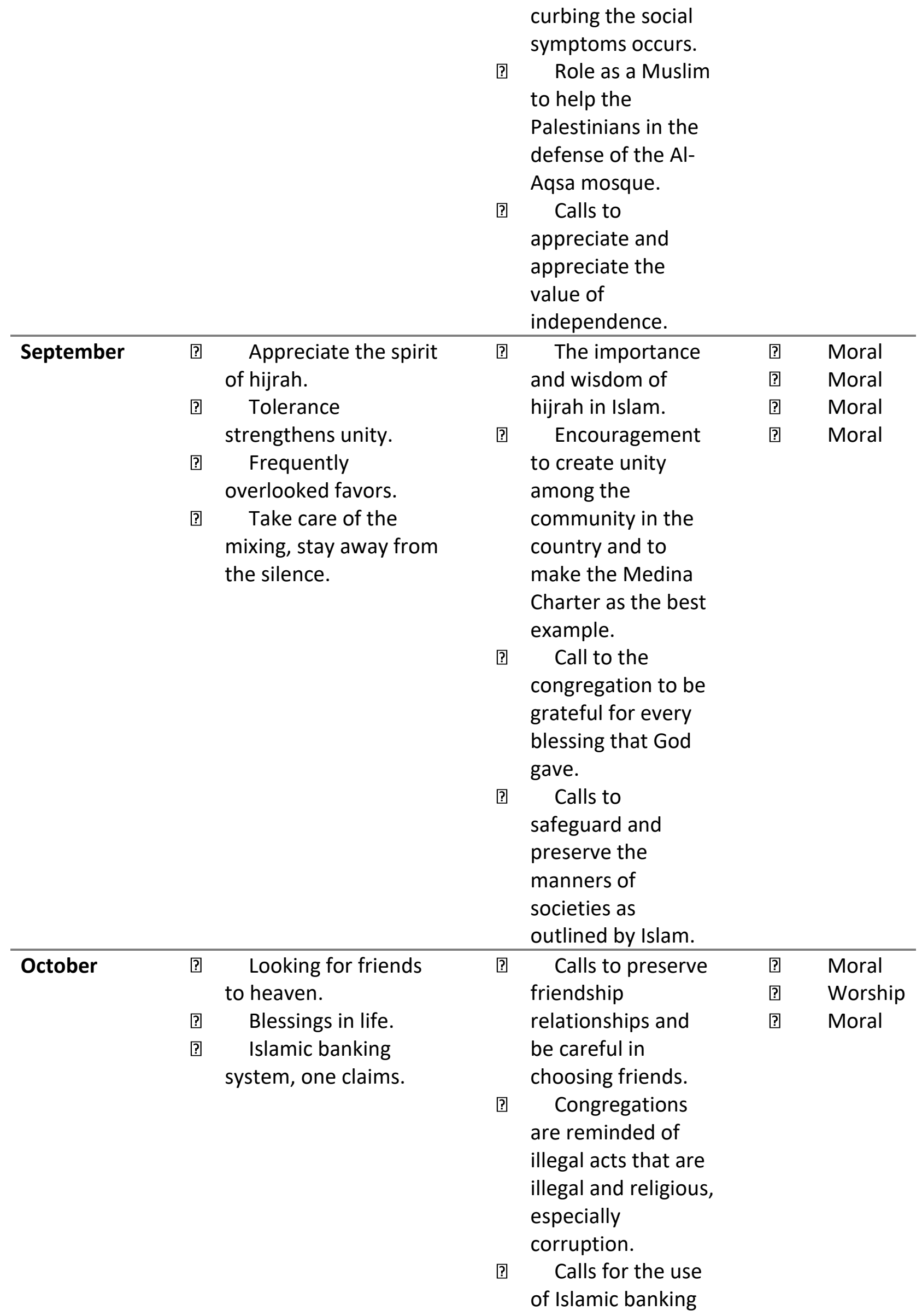




\begin{tabular}{|c|c|c|c|c|c|c|}
\hline & & & & $\begin{array}{l}\text { services to manage } \\
\text { the property well. }\end{array}$ & & \\
\hline & & & ? & $\begin{array}{l}\text { Factors and } \\
\text { causes of mental } \\
\text { problems occur. }\end{array}$ & & \\
\hline & & & 回 & $\begin{array}{l}\text { The call towards } \\
\text { self-describing in } \\
\text { worship. }\end{array}$ & & \\
\hline & & & 回 & $\begin{array}{l}\text { A reminder to } \\
\text { avoid envy because } \\
\text { it is a disastrous } \\
\text { act. }\end{array}$ & & \\
\hline & & & 回 & $\begin{array}{l}\text { The virtues of } \\
\text { volunteers. }\end{array}$ & & \\
\hline November & 回 & Parents are among & 回 & Emulate & 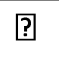 & Moral \\
\hline & & the success factors of & & LuqmanulHakim & 囵 & Moral \\
\hline & & the child. & & and appreciate & 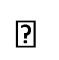 & Worship \\
\hline & 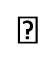 & Personality of the & & Ibrah from the & 回 & Worship \\
\hline & & Prophet PBUH & & given order. & ? & Worship \\
\hline & 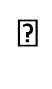 & God's Test a & 回 & Congregations & & \\
\hline & ? & Repentance, Liver & & emulate the morals & & \\
\hline & & hygiene Factor. & & of the Prophet & & \\
\hline & 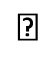 & Economic & & PBUH. & & \\
\hline & & sustainability, well- & ? & The wisdoms & & \\
\hline & & being of the people. & & behind every & & \\
\hline & & & & $\begin{array}{l}\text { disaster and test } \\
\text { that God revealed } \\
\text { to mankind. }\end{array}$ & & \\
\hline & & & 回 & Make a way to & & \\
\hline & & & & always perform & & \\
\hline & & & & repentance to & & \\
\hline & & & 回 & The & & \\
\hline & & & & responsibility and & & \\
\hline & & & & persistence of the & & \\
\hline & & & & government to & & \\
\hline & & & & ensure that the & & \\
\hline & & & & $\begin{array}{l}\text { people live in } \\
\text { prosperity. }\end{array}$ & & \\
\hline December & 回 & Zakat Is Not Just & 回 & Khatib urged and & ? & Worship \\
\hline & & Fitrah & & reminded the & 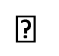 & Moral \\
\hline & 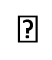 & Carrying out social & & Congregation to & ? & Worship \\
\hline & & responsibility & & perform zakat & 回 & Faith \\
\hline & 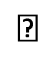 & Troubled by life & & obligations. & ? & Moral \\
\hline & & passed. & 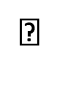 & $\begin{array}{l}\text { Congregations } \\
\text { are urged to }\end{array}$ & & \\
\hline
\end{tabular}




Eclipse
Phenomenon: Proof of
Divine Supremacy
(Special Sermon)
The Role of Parents
and Society To Prevent
Depression.

\author{
maintain \\ relationships and \\ harmony with all \\ creatures of God \\ regardless of race \\ and religion. \\ ? Congregations \\ are urged to focus \\ on worship, \\ employment, social \\ life \& da'wah. \\ ? Congregations \\ are urged to take \\ ibrah from the \\ eclipse \\ phenomenon as \\ evidence of the \\ power, greatness \\ and matiness of \\ Allah TAALA. \\ ? Be reminded of \\ the responsibility of \\ each parent in \\ educating the \\ children so that the \\ children do not do \\ things that bring \\ about God's wrath.
}

Based on the data in table 1 , it is found that $47 \%$ of the topics discussed in the text of the Friday sermon in Negeri Sembilan are themed on worship, followed by $38 \%$ are themed on morality while $15 \%$ are themed on faith. This shows that Negeri Sembilan attaches great importance to the topic of worship to be applied in the life of the Muslim community in Negeri Sembilan.

Worship plays a very important role in the formation of a Muslim community that prioritizes religion and obeys religious injunctions. Effective worship can shape the personality of the Muslim community in Negeri Sembilan to be more steadfast to the faith and practice the true Islamic way of life. In fact, with worship as well, praiseworthy qualities can be nurtured and reprehensible qualities can be prevented. According to Ibn Taymiyyah, "worship is all things that are pleasing and pleasing to God, whether words, outward and inward deeds"

Therefore, as a state with a population percentage of $60.3 \%$ consisting of Muslims, (2010 census), Negeri Sembilan has always been committed to upholding and upholding the value of religious values in the daily life of the Muslim community. This is in line with the vision and mission of the Negeri Sembilan Islamic Religious Council to be the foremost in leading the 
development of the ummah and Islamic teachings and responsible as the highest Islamic body in Negeri Sembilan in preserving the sanctity of Islam and determining policies to generate ummah development in various fields based on Islamic law. (MAINS website)

Thus, the table above clearly shows that the aspect of worship in the text of the Friday sermon is touched and discussed by the panel of writers and reviewers of the text of the sermon JHEAINS in the production of the text of the Friday sermon without ignoring the aspects of faith and morality which are also important in religious appreciation. Under the social problems plaguing the society, the title of worship presented is hoped to stimulate the spirit of the Muslim community to always improve themselves and worship to a path that is more pleasing to Allah S.W.T.

\section{Conclusion}

As a comprehensive religion and encompasses all aspects of life including aspects of faith, morality, and worship, Islam has a mechanism in dealing with the changes of the times in line with technological advances. Similarly, the sermon is an important platform in conveying messages and advice to motivate the community towards the formation of the self in line with Islamic law. This study aims to examine the themes found in the Friday sermon in Negeri Sembilan in accordance with the objectives and target audience.

The Friday sermon is an effective communication platform to be used in conveying the message of Islam and even the best way of maw'zah to be kind to the Muslim community once a week. Because of that, the theme chosen for the sermon writing should be interesting and appropriate to the background and education of the targeted mad'u so that the message to be conveyed can achieve its objectives and goals and in line with the spiritual needs of today's society.

\section{Corresponding Author}

Mizzuan bin Jafilus

Research Centre for Da'wah and Leadership, Faculty of Islamic Studies, National University of Malaysia, 43600, Bangi, Selangor

Email: mizzuan.ukm@gmail.com.

\section{References}

Al Quran.

Ahmad, A. (2015). Akhlak Warisan Rasulullah S.A.W Membawa Kemuliaan Umat. Jurnal Usuluddin 26 (26).

As'ad, A. (2017). Penggunaan Bahasa Untuk Meningkatkan Efektivitas Pesan Khutbah Jumaat. INJECT (Interdisciplinary Journal Of Communication), 2 (2),161.

Bakar, M. H., Tajudin, F. S. (2007). Keberkesanan Komunikasi Dakwah: Kajian Analisis Kandungan Terhadap Teks Khutbah Jumaat Jabatan Kemajuan Islam Malaysia (JAKIM).

Ghani, Z., \& Salimah, A. M. (2006). Penghayatan Agama Sebagai Asas Pembangunan Pelajar: Analisis Terhadap Beberapa Pandangan Al-Imam Al-Ghazali. National Student Development Conference (NASDEC), (pp. 1- 19).

Husain, F., \& Kasim, T. S. A. T. (2006). Pendekatan Psikologi Dalam Pendidikan Akhlak Muslim Sebagai Pemangkin Pembangunan Insan dan Tamadun. Jurnal Pengajian Melayu, 17, 290- 306. 
Hamat, M. F. (2008). Cabaran Pengukuhan Akidah. Jurnal Penyelidikan Islam, 21:13-32.

Hamdan, Y. (2005). Karakteristik Khutbah Jumaat di Mesjid Kampus: Perspektif Komunikasi. Mediator. Jurnal Komunikasi 8 (2), 353 -68

Khalid, I. (2017). Akar- akar Dakwah Islamiyah (akidah, ibadah, syariah). Orasi Jurnal Dakwah dan Komunikasi, 8 (1), 68-85.

Ripin, M. H. C. Z. (2005). "Konsep Tamadun Islam" dalam Tamadun Islam dan Tamadun Asia. Skudai: Pusat Pengajian Islam dan Pembangunan Sosial Universiti Teknologi Malaysia.

Sulong, J. (2016). Pemeliharaan Akidah Islam: Analisis daripada Sudut Penguatkuasaan Undang Undang. Afkar 18 (special Issue). 1-34

Samuri, M. A. M., \& Hopkins. (2018). Voices of Islamic Authorities Friday Khutba in 28 (August). 47-67. 